ORIGINAL ARTICLE

\title{
Development of the red gum lerp psyllid Glycaspis brimblecombei (Hemiptera: Aphalaridae) in Eucalyptus spp.
}

\author{
Desenvolvimento do psilídeo-de-concha Glycaspis brimblecombei (Hemiptera: \\ Aphalaridae) em Eucalyptus spp. \\ Jaqueline Magalhães Pereira' (D), Edson Luiz Lopes Baldin² (D), Everton Pires Soliman³ (D), \\ Carlos Frederico Wilcken² \\ ${ }^{1}$ Universidade Federal de Goiás - UFG, Goiânia, GO, Brasil \\ 2Universidade Estadual Paulista - UNESP, Botucatu, SP, Brasil \\ ${ }^{3}$ Suzano Papel e Celulose, Itapetininga, SP, Brasil
}

\begin{abstract}
How to cite: Pereira, J. M., Baldin, E. L. L., Soliman, E. P., \& Wilcken, C. F. (2020). Development of the red gum lerp psyllid Glycaspis brimblecombei (Hemiptera: Aphalaridae) in Eucalyptus spp. Scientia Forestalis, 48(127), e3283.
\end{abstract} https://doi.org/10.18671/scifor.v48n127.18

\begin{abstract}
The red gum lerp psyllid, Glycaspis brimblecombei Moore (Hemiptera: Aphalaridae), is considered one of the most important pests of Eucalyptus worldwide. Since its detection in Brazil in 2003, the insect has caused defoliation in forests, twig dieback and sooty mold. Several types of management were evaluated, but few studies focused on the search for resistant Eucalyptus species and hybrid clones. The present study aimed to assess the biological performance of G. brimblecombei on E. camaldulensis, E. urophylla, and E. grandis and on the hybrids E. grandis $\times$ E. camaldulensis (1277 and 3025), E. urophylla $\times$ E. camaldulensis (VM-01), and E. urophylla $\times$ E. grandis (C-219, H-13, GG-100 and I-144), in order to determine resistance mechanisms. Under laboratory conditions $\left(T=26 \pm 2^{\circ} \mathrm{C} ; \mathrm{RH}=60 \pm 10 \%\right.$; photoperiod= $12 \mathrm{~h}$ ), psyllids on each of the ten Eucalyptus genotypes were evaluated daily until adult emergence. Genotypes C-219 and H-13 (E. urophylla $\times$ E. grandis) exhibited high levels of antibiosis and/or antixenosis (nonpreference) resistance to $G$. brimblecombei, drastically reducing nymph viability (mortality $>80 \%$ ). In turn, genotypes 3025 (E. grandis $\times$ E. camaldulensis) and E. camaldulensis were highly susceptible to the biological development of red gum lerp psyllids. Our results may contribute to genetic improvement programs aimed at obtain G. brimblecombei resistant Eucalyptus genotypes.
\end{abstract}

Keywords: Antibiosis; Antixenosis; Forest pest; Host plant resistance.

\section{Resumo}

O psilídeo-de-conha Glycaspis brimblecombei Moore (Hemiptera: Aphalaridae), é considerado uma das mais importantes pragas de eucalipto em todo o mundo. Desde a sua detecção no Brasil, em 2003, o inseto causa desfolha em florestas, secamento de ponteiros e possibilita o desenvolvimento de fumagina. Várias estratégias de controle foram avaliadas, mas poucos estudos têm-se centrado na busca de clones de espécies e híbridos de eucalipto resistentes. O presente estudo teve como objetivo avaliar o desempenho biológico do G. brimblecombei nas espécies E. camaldulensis, E. urophylla, E. grandis e híbridos E. grandis x E. urophylla (C-219, H-13, GG-100 e I-144), E. uropylla x E. camaldulensis (VM-01) e E. grandis $x$ E. camaldulensis (1277 e 3025), a fim de determinar mecanismos de resistência. Sob condições de laboratório $\left(T=26 \pm 2^{\circ} \mathrm{C}\right.$; UR $=60 \pm 10 \%$; fotoperíodo $=12 \mathrm{~h}$ ), a biologia do psilídeos foi avaliada nos dez genótipos de eucalipto, diariamente até a emergência de adultos. Os genótipos C-219 e H-13 ( $E$. urophylla $\times$ E. grandis) expressaram altos níveis de antibiose e/ou antixenose (não preferência) resistência a G. brimblecombei, reduzindo drasticamente a viabilidade ninfal (mortalidade > 80\%). Os genótipos 3025 (E. grandis $\times$ E. camaldulensis) e E. camaldulensis foram considerados altamente suscetíveis, pois foram

Financial support: This work was supported by the Fundação de Amparo à Pesquisa do Estado de São Paulo (2009/50815-5) and Forestry Science and Research Institute - IPEF.

Conflict of interest: Nothing to declare.

Corresponding author: jmpereira@ufg.br

Received: 12 February 2019.

Accepted: 10 October 2019.

Editor: Francides Gomes da Silva Júnior.

(c) This is an Open Access article distributed under the terms of the Creative Commons Attribution License, which permits unrestricted use, This is an Open Access article distributed under the terms of the Creative Commons Attributi
distribution, and reproduction in any medium, provided the original work is properly cited. 
favoráveis ao desenvolvimento biológico do psilideo-de-conha. Nossos resultados podem contribuir para programas de melhoramento genético visando obter genótipos de eucalipto resistentes a $G$. brimblecombei.

Palavras-chave: Antibiose; Antixenose; Praga florestal; Resistência de plantas.

\section{INTRODUCTION}

The red gum lerp psyllid Glycaspis brimblecombei Moore (Hemiptera: Aphalaridae), native to Australia, has spread rapidly to other regions. G. brimblecombei was first reported in Brazil in June 2003, in the state of São Paulo, and quickly spread to other states (Santana \& Burckhardt, 2007). The insect has several generations a year, with populations dropping under unfavorable conditions (Laudonia et al., 2014). The infestation is easily confirmed by the presence of conical coverings (lerps) secreted by the nymphs (Cuello et al., 2018).

Both adults and nymphs cause damage by sucking the sap from the phloem of plants. Their attack can cause leaf deformation and small leaves as well as twig dieback, with severe infestations leading to plant death. Psyllids also produce large amounts of honeydew, favoring the occurrence of sooty mold and increasing the Eucalyptus susceptibility to other insects (Paine et al., 2006; Peris-Felipo et al., 2011). The productivity of eucalyptus plantations declined considerably after the establishment of this insect in Brazil (Wilcken et al., 2015). Defoliation of 20 to 30\% was observed in the E. grandis x E. urophylla clone (Wilcken et al., 2003). For E. camaldulensis, tree mortality ranges from 20 to 95\% (Wilcken et al., 2015).

Psyllids feed on a wide variety of Eucalyptus species, but some G. brimblecombei feed exclusively on Eucalyptus, section Exsertaria (Collett, 2000), especially E. camaldulensis, although this psyllid has been recorded in over twenty Eucalyptus species (Brennan et al., 2001).

Studies have been performed worldwide with a view to developing chemical, cultural and biological management strategies to control red gum lerp psyllid populations, but few assess the resistance of eucalyptus species to this insect (Brennan et al., 2001; Petro et al., 2017).

Host plant resistance is an important tool in integrated pest management (IPM) systems and reduces insect pest populations to below the economic injury level without causing an environmental imbalance, in addition to being compatible with other control methods (Henery, 2011; Smith \& Clement, 2012). Resistant plants can negatively affect insect biology and behavior, altering plants' ability to withstand large pest populations without significant yield losses (Smith \& Clement, 2012).

Brennan et al. (2001) studied the resistance of 21 Eucalyptus species to G. brimblecombei based on the presence of eggs, nymphs and defoliation. The species E. cinerea, E. cladocalyx, C. ficifolia, E. globolus (juvenile leaves), E. paniculata, E. polyanthemos, E. pulverulenta, E. robusta, E. saligna and E. spathulata were deemed resistant, but E. camaldulensis and E. tereticornis were rated highly susceptible. Leaf epicuticular wax appears to be involved in resistance, since the resistant species have glaucous leaves.

Firmino-Winckler et al. (2009) evaluated the biological development of red gum lerp psyllids on eucalyptus species (E. camaldulensis, E. grandis, E. urophylla and C. citriodora) and one $E$. urophylla $\times \mathrm{E}$. grandis hybrid. The low attractiveness and oviposition observed in $E$. grandis and $E$. urophylla suggests non-preference resistance (Pereira et al., 2013).

Considering the expansion of Eucalyptus cultivation in Brazil (Indústria Brasileira de Árvores, 2018) and the growing importance of G. brimblecombei in forests (Wilcken et al., 2015), it is important to investigate the resistance of Eucalyptus hybrids to the red gum lerp psyllid. This study assessed the development of G. brimblecombei on ten Eucalyptus genotypes to identify possible resistance mechanisms. 


\section{MATERIAL AND METHODS}

\section{Obtaining Eucalyptus spp. genotypes}

The biological performance of G. brimblecombei on approximately 100-day-old seedlings of several Eucalyptus genotypes was monitored. This assay used the species and hybrids described in Table 1. The Eucalyptus genotypes were chosen based on information regarding their resistance (E. grandis) or susceptibility (E. camaldulensis), and the importance of the commercially planted area. Commercial hybrid clones and their associated species were also used.

Table 1. Eucalyptus genotypes used in tests for resistance to Glycaspis brimblecombei and their genealogies.

\begin{tabular}{cc}
\hline Genotypes & Provenance or Genealogy \\
\hline E. camaldulensis IPEF (seeds) & Itatinga, SP, Brazil \\
E. grandis (seeds) & Lençóis Paulista, SP, Brazil \\
E. urophylla (seeds) & Flores, Indonesia \\
3025 & E. grandis $\times$ E. camaldulensis \\
1277 & E. grandis $\times$ E. camaldulensis \\
VM-1 & E. urophylla $\times$ E. camaldulensis \\
H-13 & E. urophylla $\times$ E. grandis \\
I-144 & E. urophylla $\times$ E. grandis \\
C-219 & E. urophylla $\times$ E. grandis \\
GG-100 & E. urophylla $\times$ E. grandis
\end{tabular}

\section{Biology assessment}

The present study was performed under controlled conditions ( $T=26 \pm 2^{\circ} \mathrm{C}, \mathrm{RH}=60 \pm 10 \%$ and photo-phase $=12 \mathrm{~h}$ ). The seedlings were grown in $200 \mathrm{~mL}$ plastic pots containing sand. Eggs (leaf disk) collected in the field were placed in Petri dishes $(100 \times 20 \mathrm{~mm})$ containing moistened filter paper and monitored daily until hatching. First instar nymphs were then transferred with a brush to the adaxial side of leaves on the middle third of seedlings of each Eucalyptus genotype tested.

Four seedlings were used per genotype, each containing on average of 70 nymphs. A completely randomized experimental design was used, with each seedling corresponding to a replicate. Assessments were carried out daily, always at the same time, using a stereomicroscope (40x magnification). Lerp size was measured at each instar, on the second day after nymph stage change of stage.

The nymphs of $G$. brimblecombei secrete a conical covering (lerp) composed of solidified honeydew (Sharma et al., 2013), which protects them until they reach adulthood (Sullivan et al., 2006). The lerp expands as nymphs grow and lerp size can therefore be easily used to characterize changes between instars (Stivanelli et al., 2009). The number of antennal segments has previously been used to determine differences between instars of $G$. brimblecombei (Firmino-Winckler et al., 2009). However, lerp size can be easily observed and allows the nymph development stage to be established without removing the lerp.

In the juvenile phase, the duration of stages, total duration of the juvenile phase, and total mortality were measured. Instar changes were determined based on differences in lerp size (Stivanelli et al., 2009), the presence of exuviae, and nymph morphological characteristics. To prevent emergent adults on different Eucalyptus genotypes from interacting, the infested leaves were covered with individual voile cages following the appearance of fifth instar nymphs.

After adult emergence, individuals were sexed by observing the terminal part of the abdomen and forceps, which are only present in males. Recently emerged red gum lerp psyllid 
pairs from different Eucalyptus genotypes were then placed separately in cages, consisting of plastic Petri dishes $(60 \mathrm{~mm} \times 15 \mathrm{~mm}$ ) attached to the leaves of the respective genotype seedlings, for egg laying and to measure longevity with food (seedlings). The number of eggs laid and their viability were determined. Other recently emerged adults were placed in test tubes (one individual per tube) containing cotton moistened with distilled water and sealed with parafilm evaluate longevity without food.

\section{Statistical analysis}

The data obtained were submitted to analysis of variance (ANOVA) using the $F$ test treatment means compared using Tukey's test $(P \leq 0.05)$. Nymph mortality and adult longevity data were transformed with $\arcsin (x / 100)^{1 / 2}$ and $(x+1)^{1 / 2}$, respectively, to meet ANOVA assumptions, but the original values are presented in Figures 1 and 2 .

\section{RESULTS AND DISCUSSION}

Following nymph infestation of the adaxial side of E. camaldulensis leaves and hybrids of this species $(3025,1277$ and VM-1), some individuals moved to the abaxial side, while others remained on the upper surface. However, in E. grandis, E. urophylla and E. urophylla $\times$ E. grandis (C-219, H-13, I-144 and GG-100), most individuals migrated to the abaxial side.

Nymph migration to the abaxial surface can be explained by their oviposition behavior. G. brimblecombei females prefer to lay their eggs on the abaxial surface of eucalyptus leaves (Silva et al., 2010, Pereira et al., 2013; Tuller et al., 2017).

Five $G$. brimblecombei nymph instars were observed in all the genotypes tested. The mean lerp diameter was $0.95 \pm 0.01 \mathrm{~mm}$ for first instar nymphs, and $1.11 \pm 0.02,1.57 \pm 0.04,2.30 \pm$ 0.03 , and $2.69 \pm 0.05 \mathrm{~mm}$ for second, third, fourth and fifth instars, respectively.

In general, the first and fifth instars lasted longer than the remaining instars (Table 2). The first instar was significantly shorter for genotypes 3025 (E. grandis $\times$ E. camaldulensis) and E. camaldulensis and longer for C-219, while the second instar was longer for C-219, I-144, H13 (E. urophylla $\times$ E. grandis) and E. urophylla. The second instar was shorter for E. camaldulensis, 1277 and 3025 (E. grandis $\times$ E. camaldulensis). The third instar was longer for E. urophylla and shorter for 3025 (E. grandis x E. camaldulensis). No significant differences were observed between fourth and fifth instar duration.

Table 2. Duration in days (mean $\pm \mathrm{SE}$ ) of the instars and nymph periods of Glycaspis brimblecombei in Eucalyptus genotypes (12:12 L:D, $\left.26 \pm 2{ }^{\circ} \mathrm{C}, 60 \pm 10 \% \mathrm{RH}\right)$.

\begin{tabular}{|c|c|c|c|c|c|c|}
\hline Genotype $^{1}$ & $1^{\text {st }}$ instar $^{2}$ & $2^{\text {nd }}$ instar ${ }^{2}$ & $3^{\text {rd }}$ instar ${ }^{2}$ & $4^{\text {th }}$ instar $^{2}$ & $5^{\text {th }}$ instar $^{2}$ & $\begin{array}{l}\text { Nymphal } \\
\text { period }^{2}\end{array}$ \\
\hline C-219 & $4.19 \pm 0.32 \mathrm{a}$ & $2.72 \pm 0.20 \mathrm{a}$ & $2.74 \pm 0.10 a b$ & $2.83 \pm 0.09 a$ & $3.96 \pm 0.29 a$ & $15.20 \pm 0.65 a$ \\
\hline E. grandis & $3.99 \pm 0.31 \mathrm{ab}$ & $2.36 \pm 0.07 a b$ & $2.55 \pm 0.17 a b$ & $2.46 \pm 0.17 a$ & $3.24 \pm 0.23 a$ & $13.89 \pm 0.16 a b$ \\
\hline $\mathrm{I}-144$ & $3.90 \pm 0.30 a b$ & $2.76 \pm 0.06 a$ & $2.54 \pm 0.08 a b$ & $2.43 \pm 0.15 a$ & $3.61 \pm 0.15 a$ & $14.34 \pm 0.17 a b$ \\
\hline E. urophylla & $3.55 \pm 0.15 a b$ & $2.71 \pm 0.19 a$ & $2.78 \pm 0.19 a$ & $2.70 \pm 0.11 a$ & $3.12 \pm 0.11 a$ & $14.22 \pm 0.54 a b$ \\
\hline $\mathrm{H}-13$ & $3.67 \pm 0.29 a b$ & $2.73 \pm 0.14 a$ & $2.72 \pm 0.31 \mathrm{ab}$ & $2.73 \pm 0.30 a$ & $3.75 \pm 0.43 a$ & $14.06 \pm 0.46 a b$ \\
\hline VM-1 & $3.41 \pm 0.15 a b$ & $2.32 \pm 0.06 a b$ & $2.36 \pm 0.11 a b$ & $2.71 \pm 0.21 \mathrm{a}$ & $3.46 \pm 0.71 a$ & $13.86 \pm 0.26 a b$ \\
\hline GG-100 & $3.34 \pm 0.13 a b$ & $2.39 \pm 0.07 a b$ & $2.74 \pm 0.09 a b$ & $2.73 \pm 0.09 a$ & $3.57 \pm 0.09 a$ & $14.37 \pm 0.26 a b$ \\
\hline 1277 & $3.30 \pm 0.07 a b$ & $2.18 \pm 0.02 b$ & $2.49 \pm 0.08 a b$ & $2.71 \pm 0.09 a$ & $3.71 \pm 0.19 a$ & $13.90 \pm 0.26 a b$ \\
\hline E. camaldulensis & $3.06 \pm 0.03 b$ & $2.06 \pm 0.02 b$ & $2.17 \pm 0.02 a b$ & $2.37 \pm 0.03 a$ & $3.89 \pm 0.11 a$ & $13.41 \pm 0.11 b$ \\
\hline 3025 & $3.05 \pm 0.03 b$ & $2.08 \pm 0.02 b$ & $2.06 \pm 0.02 b$ & $2.51 \pm 0.07 a$ & $3.54 \pm 0.08 a$ & $13.16 \pm 0.14 b$ \\
\hline$F_{9,30}$ & $3.37 * \star$ & $6.76^{\star \star}$ & $3.06 *$ & $1.07^{\mathrm{ns}}$ & $1.61^{\mathrm{ns}}$ & $2.59 *$ \\
\hline
\end{tabular}

${ }^{1} \mathrm{C}-219, \mathrm{I}-144, \mathrm{H}-13$ and GG-100 (E. urophylla $\times$ E. grandis); 1277 and 3025 (E. grandis $\times$ E. camaldulensis); VM-1 (E. urophylla $x$ E. camaldulensis). ${ }^{2}$ Original data. Means followed by the same letter in the column do not differ significantly according

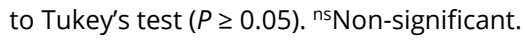


The nymph stage was shorter for nymphs grown on Eucalyptus genotype 3025 (E. grandis $\times$ E. camaldulensis) and E. camaldulensis, and longer for C-219 (E. urophylla X E. grandis). Considering the entire nymph stage (Figure 1), genotypes E. camaldulensis and 3025 (E. grandis $\times$ E. camaldulensis) exhibited significantly lower mortality and $\mathrm{H}-13$ (E. urophylla $\times$ E. grandis) provided greater nymph mortality (96.31\%).

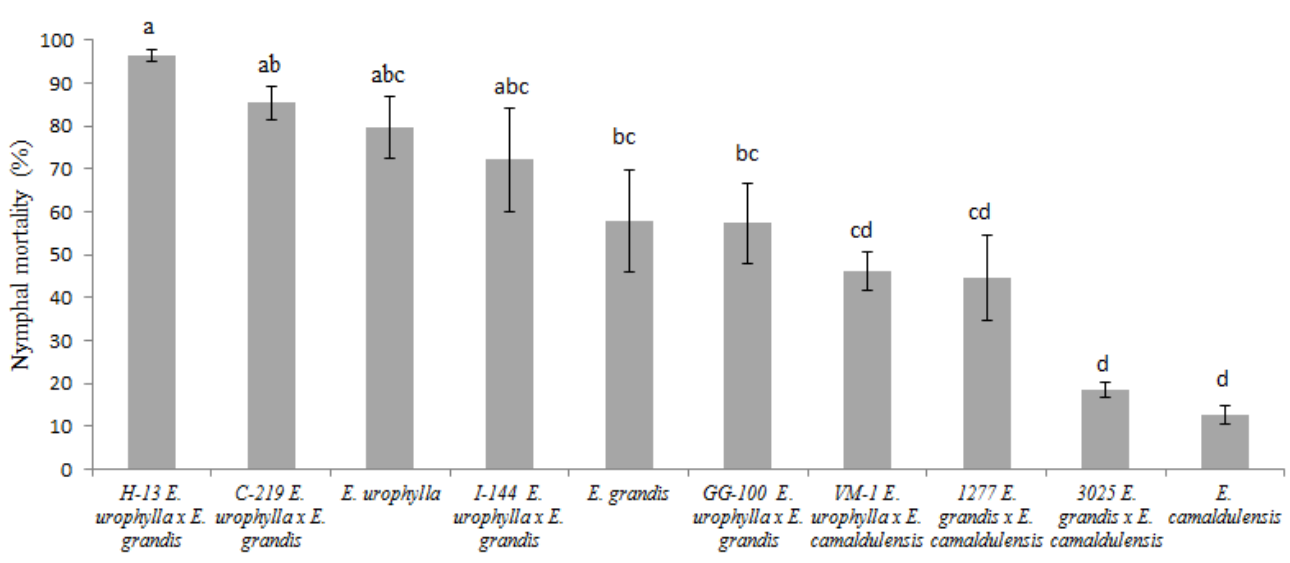

Figure 1. Nymph mortality (\%) of Glycaspis brimblecombei in Eucalyptus genotypes (12:12 L:D, $26 \pm 2{ }^{\circ} \mathrm{C}$, $60 \pm 10 \% \mathrm{RH})$. Means followed by the same letter in the column do not differ significantly according to

Tukey's test $(P \geq 0.05)$. Original data. Data were transformed to arc $\sin (x / 100)^{1 / 2}$ for analysis. $\left(F_{9,30}=\right.$

15.10, $P<0.01$ ). C-219, I-144, H-13 and GG-100 (E. urophylla $\times$ E. grandis); 1277 and 3025 (E. grandis $\times E$. camaldulensis); VM-1 (E. urophylla $\times$ E. camaldulensis).

Nymphs fed with E. camaldulensis and 3025 (E. grandis x E. camaldulensis) exhibited shorter nymphal stages, indicating that these genotypes were more suitable for their development, corroborating the findings of Firmino-Winckler et al. (2009), Ribeiro et al. (2015), and Cuello et al. (2018). The longer nymph stage observed for C-219 (E. urophylla $\times$ E. grandis) indicates the occurrence of antibiosis and/or antixenosis.

In addition, the high mortality rates (Figure 1 ) in the nymph stage of all the C-219, $\mathrm{H}-13$, I144 (E. urophylla $\times$ E. grandis) and E. urophylla individuals demonstrate a high level of antibiosis and/or antixenosis for these genotypes. E. grandis and E. urophylla display non-preference as a resistance mechanism to $G$. brimblecombei, due to low attractiveness and oviposition (Pereira et al., 2013).

Longer insect development stages or life cycles indicate that the plant has a negative effect on insect biology, characteristic of antibiosis resistance. However, extended developmental stages may also be related to antixenosis, due to lower food intake by insects (Smith \& Clement, 2012). These resistance mechanisms (antibiosis or antixenosis) could not be differentiated because the volume of insect droppings was not quantified.

E. urophylla and $E$. grandis and some of their hybrids showed high nymphal mortality, which could explain why Petro et al. (2017) found no G. brimblecombei on E. grandis. In E. dunni, Cuello et al. (2018) observed high G. brimblecombei mortality in the first and second nymph instars. Insect mortality may increase with poor diet; as such, low concentrations of certain nutrients may be plant defense strategies to which insects respond by ingesting more food over longer time periods (Haukioja, 1990).

Some host plant characteristics may be associated with differences in nymph development and oviposition. In addition, Eucalyptus leaves also display high levels of secondary compounds such as tannins, phenols and essential oils, which can be considered defenses against phytophagous insects (Ohmart \& Edwards, 1991). However, G. brimblecombei adults avoid the oil glands, directing their stylets around them (Brennan \& Weinbaum, 2001a). According to Ribeiro et al. (2015), the high mortality of G. brimblecombei nymphs in eucalyptus genotypes may be related to greater leaf lignin concentrations ( $C$. citriodora), high total phenol 
content and the presence of epicuticular wax. In this context, Lucia et al. (2016) recorded elevated 1,8-cineole levels in eucalyptus that exhibited a low $G$. brimblecombei abundance, whereas terpenes $\alpha$-and $ß$ - phellandrene were the main components in eucalyptus with a high abundance of psillyds.
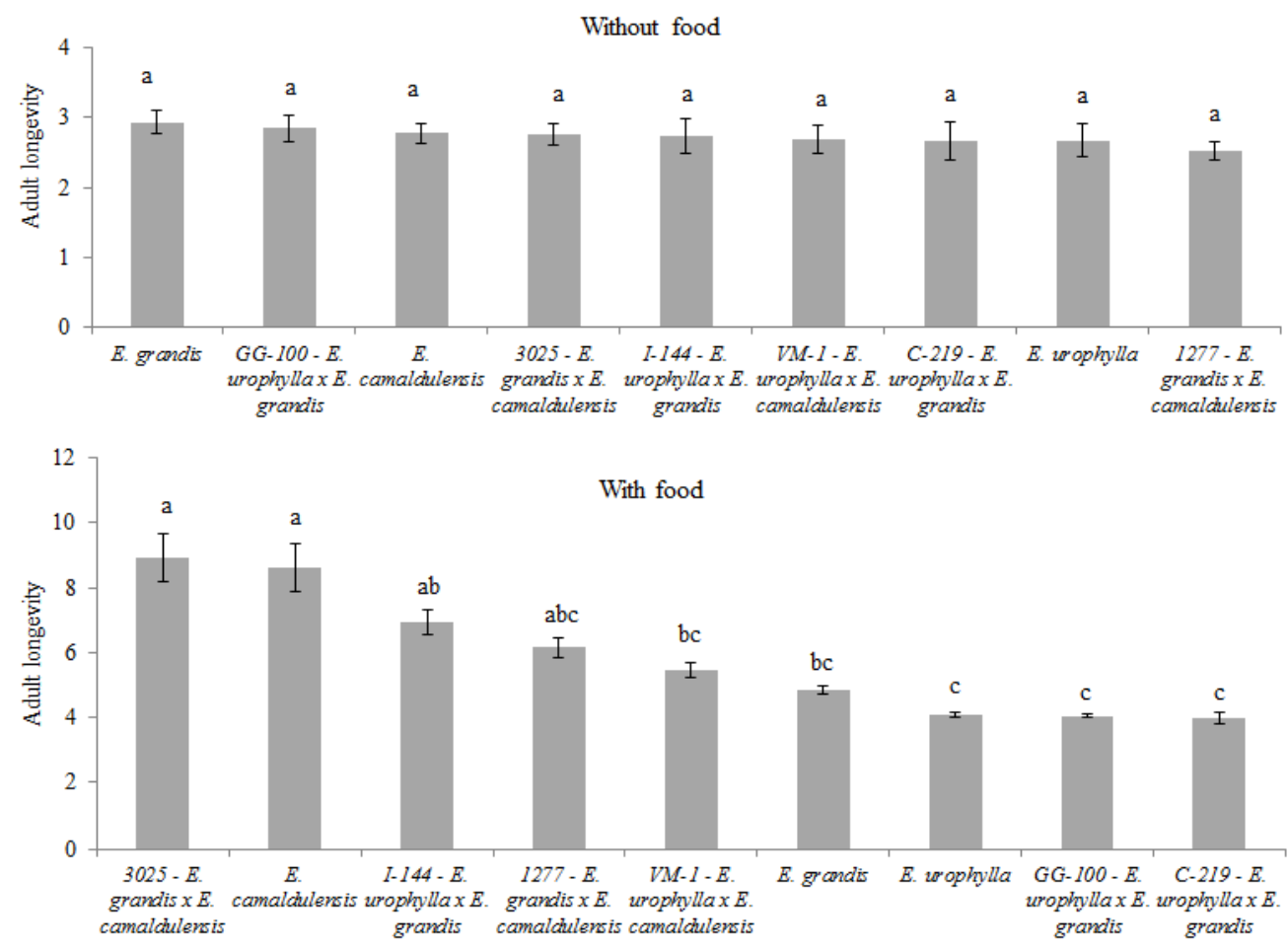

Figure 2. Longevity in days (mean $\pm \mathrm{SE}$ ) of adult Glycaspis brimblecombei fed or not with Eucalyptus genotypes (12:12 L:D, $\left.26 \pm 2{ }^{\circ} \mathrm{C}, 60 \pm 10 \% \mathrm{RH}\right)$. Means followed by the same letter in the column do not differ significantly according to Tukey's test $(P \geq 0.05)$. ${ }^{\circ}$ Original data. Data were transformed $(x+1)^{1 / 2}$ for analysis. Without food $\left(F_{9,28}=0.62, P=0.77\right)$ and with food $\left(F_{8,25}=8.20, P<0.01\right)$. C-219, I-144 and GG-

100 (E. urophylla $\times$ E. grandis); 1277 and 3025 (E. grandis $\times$ E. camaldulensis); VM-1 (E. urophylla $\times$ E. camaldulensis). Genotype $\mathrm{H}-13$ (E. urophylla $\times$ E. grandis) was excluded from this assessment due to its high nymphal mortality.

The resistance of Eucalyptus genotypes may be linked to the presence of leaf wax, which can improve or prevent insect oviposition, movement and feeding in addition to affecting locomotion and fixation to the surface (Eigenbrode \& Espelie, 1995). Epicuticular wax has been found to negatively affect the survival and feeding behavior of $G$. brimblecombei on the young leaves of E. globulus (Brennan \& Weinbaum, 2001b). The larger amounts of epicuticular wax on the leaves of $E$. globulus resulted in lower adhesion of $G$. brimblecombei to the leaf surface (Brennan \& Weinbaum, 2001c). This wax may be a possible cause of the resistance observed in this study, since its quantity and structure varies among different Eucalyptus species (Wirthensohn \& Sedgley, 1996), which may also be related to the migration of nymphs observed in E. grandis and E. urophylla and their hybrids.

The Eucalyptus genotype on which the psyllids developed did not influence adult longevity in the treatment without food and survived for approximately 3 days (Figure 2). However, adult longevity with food differed among Eucalyptus genotypes. Suitable genotypes for insects ( $E$. camaldulensis and 3025) enable greater longevity. The genotypes GG-100, C-219 (E. urophylla $x E$. grandis) and $E$. urophylla stood out in terms of reducing the longevity of adult psyllids.

Only a few 3025, 1277 (E. grandis x E. camaldulensis), E. camaldulensis and I-144 (E. urophylla $\times$ E. grandis) females oviposited (Table 3). The number of eggs was higher for clone 
3025 and E. camaldulensis. This result was expected because these genotypes show a high oviposition preference (Pereira et al., 2013).

Table 3. Number of eggs per female (means \pm SE) and egg viability (means \pm SE) of G. brimblecombei on Eucalyptus genotypes (12:12 L:D, $\left.26 \pm 2{ }^{\circ} \mathrm{C}, 60 \pm 10 \% \mathrm{RH}\right)$.

\begin{tabular}{cccc}
\hline Genotypes $^{\mathbf{1}}$ & Eggs/female $^{\mathbf{2}}$ & Viability (\%) $^{\mathbf{2}}$ & Number of females $^{\text {(fom }}$ \\
\hline E. camaldulensis & $36.83 \pm 22.77$ & $85.60 \pm 5.72$ & 6 \\
3025 & $31.27 \pm 6.05$ & $81.24 \pm 7.82$ & 11 \\
$\mathrm{I}-144$ & $15.17 \pm 4.77$ & $59.72 \pm 13.84$ & 6 \\
1277 & $15.00 \pm 2.57$ & $81.25 \pm 9.65$ & 8 \\
$\mathrm{~F}_{3,27}$ & $1.15^{\mathrm{ns}}$ & $1.23^{\mathrm{ns}}$ & -
\end{tabular}

${ }^{1} I-144$ (E. urophylla $\times$ E. grandis); 1277 and 3025 (E. grandis $\times$ E. camaldulensis). ${ }^{2}$ Original data. Means followed by the same letter in the column are do not differ significantly according to Tukey's test $(P \geq 0.05)$. ${ }^{\text {ns Non-significant }}$

In addition, E. camaldulensis Section Exsertaria species promotes the biological development of G. brimblecombei nymphs and adults, whereas E. urophylla and E. grandis did not favor insect development and belong to Section Transversaria. This result was observed in the E. urophylla and E. grandis hybrids, evident in the lower viability of eggs on I-144 (E. urophylla $\times$ E. grandis) and the absence of oviposition in C-219 and GG-100 (E. urophylla $\times E$. grandis). The genotypes $E$. urophylla $\times$ E. grandis ( $(\mathrm{C}-219$ and $\mathrm{H}-13)$ showed greater resistance to G. brimblecombei, indicating the occurrence of antibiosis and/or antixenosis.

\section{CONCLUSION}

The species E. urophylla and E. grandis and their hybrids (C-219, I-144, GG-100, and H-13) are unfavorable to the biological development of Glycaspis brimblecombei, indicating the occurrence of antibiosis and/or antixenosis resistance. E. camaldulensis and 3025 (E. grandis $x$ E. camaldulensis) are susceptible, favoring the development and reproduction of $G$. brimblecombei; demonstrating the need for frequent monitoring in the field.

\section{ACKNOWLEDGMENTS}

We thank the Conselho Nacional de Desenvolvimento Científico and Tecnológico (CNPq) for scholarship (142331/2008-2) and the Fundação de Amparo à Pesquisa do Estado de São Paulo (FAPESP) for financial support (2009/50815-5). We also want to acknowledge the Forestry Science and Research Institute - IPEF for financial support.

\section{REFERENCES}

Brennan, E. B., Hrusa, G. F., Weinbaum, S. A., \& Levison Junior, W. (2001). Resistance of Eucalyptus species to red gum lerp psyllid (Glycaspis brimblecombei) (Homoptera: Psyllidae) in San Francisco bay area. The Pan-Pacific Entomologist, 77(4), 249-253.

Brennan, E. B., \& Weinbaum, S. A. (2001a). Stylet penetration and survival of three psyllid species on adult leaves and 'waxy'and 'de-waxed'juvenile leaves of Eucalyptus globulus. Entomologia Experimentalis et Applicata, 100(3), 355-363. http://dx.doi.org/10.1046/j.1570-7458.2001.00883.x.

Brennan, E. B., \& Weinbaum, S. A. (2001b). Performance of adult psyllids in no-choice experiments on juvenile and adult leaves of Eucalyptus globulus. Entomologia Experimentalis et Applicata, 100(2), 179185. http://dx.doi.org/10.1046/j.1570-7458.2001.00862.x.

Brennan, E. B., \& Weinbaum, S. A. (2001c). Effect of epicuticular wax on adhesion of psyllids to glaucous juvenile and glossy adult leaves of Eucalyptus globulus Labillardiere. Austral Entomology, 40(3), 270277. http://dx.doi.org/10.1046/j.1440-6055.2001.00229.x.

Collett, N. (2000). Biology and control of psyllids, and the possible causes for defoliation of Eucalyptus camaldulensis Dehnh. (river red gum) in south-eastern Australia: a review. Australian Forestry, 64(2), 88-95. http://dx.doi.org/10.1080/00049158.2001.10676170. 
Cuello, E. M., López, S. N., Andorno, A. V., Hernández, C. M., \& Botto, E. N. (2018). Development of Glycaspis brimblecombei Moore (Hemiptera: Aphalaridae) on Eucalyptus camaldulensis Dehnh. and Eucalyptus dunnii Maiden. Agricultural and Forest Entomology, 20(1), 73-80. http://dx.doi.org/10.1111/afe.12230.

Eigenbrode, S. D., \& Espelie, K. E. (1995). Effects of plant epicuticular lipids on insect herbivores. Annual Review of Entomology, 40(1), 171-194. http://dx.doi.org/10.1146/annurev.en.40.010195.001131.

Firmino-Winckler, D. C., Wilcken, C. F., Oliveira, N. C., \& Matos, C. A. O. (2009). Biologia do psilídeo-deconcha Glycaspis brimblecombei Moore (Hemiptera, Psyllidae) em Eucalyptus spp. Revista Brasileira de Entomologia, 53(1), 144-146. http://dx.doi.org/10.1590/S0085-56262009000100030.

Haukioja, E. (1990). Induction of defenses in trees. Annual Review of Entomology, 36(1), 25-42. http://dx.doi.org/10.1146/annurev.en.36.010191.000325.

Henery, M. L. (2011). The constraints of selecting for insect resistance in plantation trees. Agricultural and Forest Entomology, 13(2), 111-120. http://dx.doi.org/10.1111/j.1461-9563.2010.00509.x.

Indústria Brasileira de Árvores - IBÁ. (2018). Relatório annual 2017. São Paulo. Retrieved in 2019, July 2 , from https://iba.org/images/shared/Biblioteca/IBA_RelatorioAnual2017.pdf

Laudonia, S., Margiotta, M., \& Sasso, R. (2014). Seasonal occurrence and adaptation of the exotic Glycaspis brimblecombei Moore (Hemiptera: Aphalaridae) in Italy. Journal of Natural History, 48(1112), 11-12. http://dx.doi.org/10.1080/00222933.2013.825021.

Lucia, A., Naspi, C., Zerba, E., \& Masuh, H. (2016). Infestation of Glycaspis brimblecombei Moore on thirteen Eucalyptus species and their relationship with the chemical composition of essential oils. Journal of Insects, 2016, 1-7. http://dx.doi.org/10.1155/2016/6340579.

Ohmart, C. P., \& Edwards, P. B. (1991). Insect herbivory on eucalyptus. Annual Review of Entomology, 36(1), 637-657. http://dx.doi.org/10.1146/annurev.en.36.010191.003225.

Paine, T. D., Dreistadt, S. H., Garrison, R. W., \& Gill, R. J. (2006). Eucalyptus redgum lerp psyllid (Pest Notes, No. 7460). Davis, US: University of California, Agriculture and Natural Resources, Statewide IPM Program.

Pereira, J. M., Baldin, E. L. L., Soliman, E. P., \& Wilcken, C. F. (2013). Attractiveness and oviposition preference of Glycaspis brimblecombei Moore in Eucalyptus spp. Phytoparasitica, 41(2), 117-124. http://dx.doi.org/10.1007/s12600-012-0268-7.

Peris-Felipo, F. J., Mancusi, G., Turrisi, G. F., \& Jiménez-Peydró, R. (2011). New corological and biological data of the red gum lerp psyllid, Glycaspis brimblecombei Moore, 1964 in Italy (Hemiptera, Psyllidae). Biodiversity Journal, 2(1), 13-17.

Petro, R., Mpiri, A., \& Mkude, A. (2017). Susceptibility of Eucalyptus species and clones to red gum lerp psyllid, Glycaspis brimblecombei, (Hemiptera: Psyllidae) in Mbizi Forest Plantation, Tanzania. International Journal of Environment, Agricultural Biotechnology, 2(1), 417-420. http://dx.doi.org/10.22161/ijeab/2.1.52.

Ribeiro, Z. A., Souza, B. H. S., Costa, E. N., Mendes, J. E. P., Mafia, R. G., \& Boiça Junior, A. L. (2015). Glycaspis brimblecombei Moore, 1964 (Hemiptera: Psyllidae) on eucalyptus: oviposition nonpreference and antibiosis. Euphytica, 202(2), 285-295. http://dx.doi.org/10.1007/s10681-014-1298-7.

Santana, D. L. Q., \& Burckhardt, D. (2007). Introduced Eucalyptus psyllids in Brazil. Journal of Forest Research, 12(5), 337-344. http://dx.doi.org/10.1007/s10310-007-0035-7.

Sharma, A., Raman, A., Taylor, G., \& Fletcher, M. (2013). Nymphal development and lerp construction of Glycaspis sp. (Hemiptera: Psylloidea) on Eucalyptus sideroxylon (Myrtaceae) in central-west New South Wales. Australia. Arthropod Structure \& Development, 42(6), 551-564. PMid:23948315. http://dx.doi.org/10.1016/j.asd.2013.07.005.

Silva, J. O., Oliveira, K. N., Santos, K. J., Espírito-Santo, M. M., Neves, F. S., \& Faria, M. L. (2010). Efeito da estrutura da paisagem e do genótipo de Eucalyptus na abundância e controle biológico de Glycaspis brimblecombei Moore (Hemiptera: psyllidae). Neotropical Entomology, 39(1), 91-96. PMid:20305903. http://dx.doi.org/10.1590/S1519-566X2010000100012.

Smith, C. M., \& Clement, S. L. (2012). Molecular bases of plant resistance to arthropods. Annual Review of Entomology, 57(1), 309-328. PMid:21910639. http://dx.doi.org/10.1146/annurev-ento-120710100642.

Stivanelli, A., Pessoa, M. C. P. Y., Sá, L. A. N., \& Silva, J. P. (2009). Estimativa de estádios ninfais do psilídeo-de-concha em função dos tamanhos das conchas. Revista Agroageoambiental, 1(3), 73-78. http://dx.doi.org/10.18406/2316-1817v1n32009214. 
Sullivan, D. J., Daane, K. M., Sime, K. R., \& Andrews Junior, J. W. (2006). Protective mechanisms for pupae of Psyllaephagus bliteus Riek (Hymenoptera: Encyrtidae), a parasitoid of the red-gum lerp psyllid, Glycaspis brimblecombei Moore (Hemiptera: Psylloidea). Austral Entomology, 45(1), 101-105. http://dx.doi.org/10.1111/j.1440-6055.2006.00496.x.

Tuller, J., Oliveira, K. N., Silva, J. O., Faria, M. L., Espírito-Santo, M. M., Serrão, J. E., \& Zanuncio, J. C. (2017). Glycaspis brimblecombei (Hemiptera: Psyllidae) attack patterns on different Eucalyptus genotypes. PeerJ Preprints, 5, e2783v1. https://doi.org/10.7287/peerj.preprints.2783v1.

Wilcken, C. F., Firmino-Winckler, D. C., Dal Pogetto, M. H. F. A., Dias, T. K. R., Lima, A. C. V., Sá, L. A. N., \& Ferreira Filho, P. J. (2015). Psilídeo-de-concha-do-eucalipto, Glycaspis brimblecombei Moore. In E. F. Vilela \& R. A. Zucchi (Eds.), Pragas introduzidas no Brasil: insetos e ácaros (pp. 883-897). Piracicaba: Fealq.

Wilcken, C. F., Couto, E. B., Orlato, C., Ferreira Filho, P. J., \& Firmino, D. C. (2003). Ocorrência do psilídeode-concha (Glycaspis brimblecombei) em florestas de eucalipto no Brasil (Circular Técnica IPEF, No. 201). Retrieved in 2019, July 2, from http://www.ipef.br/publicacoes/ctecnica/nr201.pdf

Wirthensohn, M. G., \& Sedgley, M. (1996). Epicuticular wax structure and regeneration on developing juvenile Eucalyptus leaves. Australian Journal of Botany, 44(6), 691-704. http://dx.doi.org/10.1071/BT9960691.

Author's contributions: JMP: data curation, formal analysis, investigation, methodology, project administration, writing - original draft, writing - review \& editing; ELLB: conceptualization, methodology, funding acquisition, project administration, resources, writing - review \& editing; CFW: methodology, funding acquisition, resources, writing - review \& editing; EPS: methodology, investigation, writing - review \& editing. 